\title{
A KARIZMATIKUS ÉS A NEOKARIZMATIKUS LEADERSHIP ÖSSZEHASONLIITÁSA
}

\author{
A KARIZMATIKUS VEZETŐ, FARKAS FERENC EMLÉKÉNEK AJÁNLOM
}

\begin{abstract}
A karizmatikus leadership a vonatkozó szakirodalom egyik legnehezebben definiálható fogalma. Középpontjában a követő vezető iránti odaadása, elköteleződése áll, amely kiváltja a követést. A követés természeténél fogva értékracionális (nem tranzakciós jellegű) és belső meggyőződésű azonosulás (nem behódolás). A Max Weber-i karizmatikus és napjaink neokarizmatikus leadership-je között az odaadás tárgya alapján tehetünk különbséget: a karizmatikus leader esetében az odaadás a vezető személye iránt nyilvánul meg, a neokarizmatikus leader esetében az általa képviselt és a szervezet jövőképének részét képezó értékek és célok iránt. A definíciós szétválasztás kapcsán rámutatok arra, hogy a két karizmatikus leadership-értelmezés visszavezethető a követő érettségére (motivációjára és problémamegoldó képességeire, készségeire). A tanulmány a szakirodalom-áttekintésre alapozott karizmatikus/neokarizmatikus fogalmi különbségtétel mellett a GLOBE-kutatás eredményeire támaszkodva bemutatja a magyar és a nemzetközi minta hasonlóságait, illetve különbségeit a három karizmatikus leadership-változó (inspiráló, jövőképpel bíró, önfeláldozó), illetve a Karizmatikus másodlagos főfaktor tekintetében. ${ }^{i}$
\end{abstract}

Kulcsszavak: karizmatikus/neokarizmatikus leadership, motiváció, érettség

\section{„A Lélek megnyilvánulásait mindenki azért kapja, hogy használjon vele."}

(1Kor 12:8)

\begin{abstract}
„A leadership nem a hatalom-gyakorlás, hanem azon képesség alapján határozható meg, miként növelhető a vezetettek hatalom-érzete. A leader legalapvetőbb munkája az, hogy további leadereket teremtsen."
\end{abstract}

(Mary Parker Follett, 1924)

\begin{abstract}
A Korintusiaknak írt 1. levélböl vett idézet a karizma fogalom bibliai eredetére utal. Nyelvünkbe a görög „Kharidzesztai” szóból került át, jelentése: kedvesnek lenni (kegyelmi ajándék). A Magyar Katolikus Lexikon a következő meghatározást adja a szó hétköznapi értelmezésére: ,a személynek az a nagy belső, lelki ereje és hatása, mellyel képes másokat irányítani, befolyásolni, függetlenül attól, hogy a befolyásolás jó vagy rossz irányba történik-e" (Diósi - Viczián, 2001).

A karizma, karizmatikus vezetés a menedzsmentirodalom egyik legnehezebben definiálható fogalma. A nehézséget nemcsak az értelmezés, meghatározás pontos fogalmi megragadhatósága jelenti, hanem a definíciók szerteágazósága, az azok mögött álló elméletek sokszínűsége és a kialakult szakmai konszenzus ebből fakadó hiánya is.

A neo (új) jelző a különböző szóösszetételekben - neogótika, neokolonializmus, neokonzervatív, neorealizmus stb. - jellemzően arra utal, hogy egy megelőző értelmezéshez képest egy lényegileg más tartalommal éled újra az adott fogalom, rendszerint a lényegesen megváltozott kontextusnak köszönhetően.
\end{abstract}

A tanulmányomban körül járni szándékozott probléma (és az ehhez kapcsolható kutatási kérdés) a következő: a vezetési-szervezeti kontextusban mi az az alapvető változás, amely a karizmatikus leadership-fogalmat lényegileg más tartalommal élesztette újjá, és hogy mi ez a lényegileg más tartalom?

Kutatási hipotéziseim a következők:

- a karizma fogalom átértelmeződése a vezetési-szervezeti kontextus paradigmatikus megváltozásának a következménye,

- a megváltozott kontextus (paradigma) egyik meghatározó tényezője az önálló problémamegoldásra képes - egyben érett személyiséggel jellemezhető szervezeti tag (munkavállaló) megjelenése a szervezetben,

- a neokarizmatikus leadership esetében ezért a követők összetettebb elvárásainak megfelelő vezetésfelfogás szükséges, azaz a neokarizmatikus értelmezés megértéshez elengedhetetlen a követői nézőpont bekapcsolása.

\footnotetext{
${ }^{i}$ A tanulmány annak az angol nyelvű előadásnak a jelentősen átdolgozott továbbfejlesztése, amely az I. Farkas Ferenc Nemzetközi Tudományos Konferencia plenáris ülésén hangzott el.
} 
A kérdés megválaszolását és a hipotézisek igazolását alapvetően elméleti síkon kísérlem meg: a szakirodalom szintézisével, illetve ütköztetésével igyekszem alátámasztani következtetéseimet. A tanulmány végén ugyanakkor egy empirikus kutatás (GLOBE) eredményei tükrében tekintem át a neokarizmatikus leadership-értelmezést és annak magyar megjelenését.

\section{Vezetési-szervezeti paradigmaváltás}

Hipotézisem szerint a neokarizmatikus újra értelmezés a vezetési-szervezeti kontextus paradigmatikus változásával magyarázható. Értelmezésemben ilyen paradigmaváltás akkor következik be, amikor vagy a szervezet külső környezetében, vagy a szervezeti tagok jellemzőiben - olykor mindkettőben - lényeges változás történik. Ez alapján öt vezetési-szervezeti paradigmát különböztetek meg (Bakacsi, 2015)2:

1. klasszikus (munkamegosztás-szabályozottság) paradigma,

2. emberi viszonyok (elégedettség-teljesítmény) paradigma,

3. magatartástudományi döntéselméleti (elkötelezett önálló problémamegoldó) paradigma,

4. versengő (külső-belső verseny) paradigma,

5. nyer-nyer (empowerment, hálózat, ko-opetíció) paradigma.

Olvasatomban a karizmatikus leadership a klasszikus, a neokarizmatikus a versengő paradigmába illeszkedő leadership-mintázat.

A klasszikus (munkamegosztás-szabályozottság) paradigma alapvető vezetői kihívása a képzetlen és motiválatlan munkaerő szervezeti teljesítményre sarkallása. Az erre adott vezetési-szervezeti megoldás lényege pedig az alábbiak szerint foglalható össze: a (felső) vezető(k) feladata és felelőssége a belső erőforrások top-down szinergia menedzsmentje, a szervezeti válasz középpontjában a munkavégzés hatékonyságát biztosító, részletekbe menő munkamegosztással, erős centralizáltsággal és szabályozottsággal jellemezhető rendszer áll, a kontroll felülröl vezényelt (vezetőközpontú) magatartáskontroll, a vezetőfelfogás (leadership) autokratikus és feladatorientált, Hersey-Blanchard-i értelemben diktáló.

A versengő (külső-belső verseny) paradigma alapvető vezetői kihívása ugyanakkor a következő: a belső komplementaritásokat hatékony menedzsmenttel megoldó, kialakult belső szervezeti rendszerekre támaszkodó szervezet a külső komplementaritások kiaknázására, a külső kapcsolatokban rejlö szinergikus lehetőségek megragadására törekszik. Alapvető vezetői kihívás az egyes szervezetek által teremtett értékek szervezetközi kapcsolati hálóban történő újra elosztásában való eredményes alkupozíciók kialakítása és menedzselése. Az erre adott vezetési-szervezeti megoldás lényege pedig az alábbiak szerint foglalható össze: kifelé forduló stratégiák (versenystratégiák, iparági
5 erő elemzés, out-sourcing), nagy üzemméretre és annak méretgazdaságos kihasználására törekvő növekedési stratégiák (diverzifikáció, M\&A), amely egyben az értéklánc mentén történő érték-újraelosztásban is erős alkupozíciót teremt. A szegmentált külső környezetre adott válaszként szervezeti differenciáltság és annak komplex koordinációs mechanizmusokkal történő integrációja, komplexebb szervezeti megoldások (mátrix). Hálózatos szervezetközi minták kialakulása, átjárható/eltünő szervezeti határok, alapvetően IT-alapra helyezett integrált külső és belső kommunikációs rendszerek. Az alaptevékenységet érett, magasrendü motivációk által vezérelt önálló problémamegoldásra képes munkavállalók végzik, akiket vezetőik kiterjedt participációval, delegálással hatalmaznak fel. A felső vezetés figyelme egyre inkább a külső környezet felé fordul (kotteri értelemben vett leader szerep megjelenése). A teljesítménykontrollt a klánkontrollal kombináló kontrollmix. Erőteljes, ismétlődő változásmenedzsment-akciók (Bakacsi, 2015, p. 31-35.).

A munkavállalói kihívásra (érett-éretlen személyiség, feladatvégrehajtásra-problémamegoldásra való alkalmasság) tanulmányomban még visszatérek.

\section{Mi a karizmatikus és a neokarizmatikus leadership közötti különbség? - szakirodalmi áttekintés}

A karizma jelentését Weber értelmezte újra és helyezte át a teológiából a szociológiába (Bass, 1999, p. 541.). Weber a karizmatikus uralmat azon az alapon különíti el gazdasági szükségletek kielégítésére alkalmas uralomformáktól, hogy az a magasabb rendü szükségletekre adott vezetői válasz: „A mindennapok gazdasági igényein túlmenő szükségleteket viszont elvileg mindig egészen másképpen fedezték, éspedig minél régebbi történeti korokat vizsgálunk, annál inkább azt látjuk, hogy az ilyen szükségletek fedezése karizmatikus alapokra épül. Ez azt jelenti, hogy pszichikai, fizikai, gazdasági, etikai, vallási vagy politikai szükség esetén nem alkalmazásban álló hivatalos személyek és nem is a szó mai értelmében vett - vagyis szaktudásként megtanult és fizetség ellenében gyakorolt - „foglalkozás” birtokosai voltak a „természetes” vezetők, hanem természetfelettinek (abban az értelemben, hogy nem mindenki számára elérhetőek) gondolt testi és szellemi tulajdonságok birtokában lévő személyek" (Weber, 1996, p. 205. - kiemelések az eredetiben, BGy).

Ez a weberi értelmezés egyértelmüvé teszi, hogy szemben a tradicionális, illetve racionális uralomformákkal, ahol az engedelmesség az elfoglalt pozíció autoritásából eredeztethető - a karizmatikus vezető autoritása személyéből fakad (Nye, 2010). Ez azonban felvet egy mind elméleti, mind gyakorlati szempontból izgalmas kérdést: a karizma vajon a hatalom vagy a leadership fogalomkörébe tartozik-e? A logikai szétválasztás elvben egyszerü: a vezetői befolyásnak megfelelő viselkedés a hatalomgyakorlás esetén az engedelmesség, a leadership

${ }^{2}$ Ezen paradigmákat a Vezetéstudomány ez évi évfordulós ünnepi különszámában egy részletesebb tanulmányban tekintem át. 
esetén a követés formáját ölti (nincs hatalom engedelmesség és leadership-követés nélkül).

Jóllehet Weber a karizmát az uralomformák között tárgyalja, „természetfeletti tulajdonságokkal” bíró személy befolyásának engedni inkább tűnik követésnek, mint engedelmességnek. Egy újabb idézettel szeretnék rámutatni arra, hogy ez a kettő Webernél keveredik: „A karizma birtokosa nekilát a rá mért feladatnak, engedelmességet követel, és a küldetésből adódóan azt is megköveteli, hogy kövessék. Az dönti el sikerét, hogy követőkre talál-e. Ha nem ismerik el a küldetését azok, akiket a küldetés címzettjeinek érez, akkor semmivé foszlik a küldetésre formált igénye, és nem tarthat igényt engedelmességre és követőkre sem. Ha viszont elismerik az igényét, akkor ő az uruk mindaddig, amíg meg tudja örizni ezt az elismerést azzal, hogy küldetése beigazolódik. De ezt a ,jogát” hogy ő az uruk, ekkor sem a többiek akaratából vezeti le - mintha mondjuk, megválasztották volna -, hanem pont fordítva: a karizmatikus képességekkel rendelkező személyt kötelesek elismerni azok, akik a küldetés címzettjei" (Weber, 1996, p. 206. - kiemelések az eredetiben, BGy).

A szövegben mind az engedelmesség, mind a követés szavak szerepelnek - lényegében azonos súllyal körül írva azt, hogy a vezetői befolyás gyakorlása miként vált át cselekvésbe.

Weber már itt „,birkózik” Barnard (1938) későbbi felismerésével, vagyis az autoritás (tekintély) és a legitimáció közötti kapcsolat megfordulásával: az autoritás azoktól eredeztethetö, akiket vezetnek, és nem azoktól, akik vezetnek (Bakacsi, 2011). Idézzük ezúttal Barnard indifferencia zóna értelmezését:

„Minden egyénben létezik egy „indifferencia-zóna”, amelyen belül az autoritás tudatos megkérdőjelezése nélkül elfogadja az utasításokat. ... Az , ,indifferenciazóna" kifejezés a következőképpen magyarázható: Ha az ésszerűen megvalósítható valamennyi utasítást sorba rendezzük aszerint, hogy az utasítás által érintett személy számára azok mennyire elfogadhatóak, akkor belátható, hogy van néhány, amely egyértelmüen elfogadhatatlan, azaz ezeknek bizonyosan nem fog engedelmeskedni, van egy másik csoport, amely többé-kevésbé közömbösek, azaz vagy elfogadhatóak, vagy éppen csak hogy elfogadhatatlanok, és a harmadik csoport minden kétséget kizáróan elfogadható. Ez utóbbi csoport az, amely az „indifferencia-zónán” belül található. Az érintett személy - legalább is, ami az autoritás kérdését illeti - elfogadja azokat az utasításokat, amelyek ebben a zónában vannak, és számára nagyjából közömbös, hogy mi ez az utasítás. Ez az utasítás belül van azon a tartományon, amelyet általában előre látott akkor, amikor a szervezettel kapcsolatba lépett" (Barnard, 1938, p. 167-169.). Az autoritás tehát Barnard nézetei szerint akkor tekinthető elfogadottnak, ha az egyén (szervezeti tag) mérlegelés nélkül a direktívák szerint cselekszik.

Követés ez, vagy engedelmesség? Az utasitások szerinti cselekvés engedelmességet, az elfogadás követést sejtet. A hatalom (uralom) mögött mindig függés áll, amelyet valami olyan jószág szűkössége, nehezen helyettesíthetősége és vagy/bizonytalansága alapoz meg, amely jószágra az engedelmeskedő vágyik, és amit a hatalomgyakorló a kontrollja alatt tart (Bakacsi, 2015, p. 153). Az engedelmeskedő az engedelmességgel (az arra való hajlandósággal) viszonozza a vágyott jószág megszerzését. A leadership követése ezzel szemben inkább csereaktusnak tekinthető (lásd Burns, 1978, p. 257-258.): a beosztott vezetői elvárások szerinti cselekvésének jutalma a - jellemzően belső (intrinsic) - motivációi mögötti szükségletek kielégítése. A kettő közötti lényeges különbség, hogy a hatalmi függéssel szemben a leader-follower viszonyban a függés jóval inkább kölcsönös.

Miből adódik ez az ambivalens (engedelmeskedő-követő) értelmezés? A karizma sajátos természetű fogalom, mivel - jóllehet személyiségre jellemző vonásnak tűnik - ténylegesen inkább egy olyan személyes hajlamra utal, amely másokat bizonyos válaszokra késztet: ahelyett, hogy a vezetők tényleges tulajdonságaira mutatna rá, inkább a követőkre gyakorolt hatásra helyezi a hangsúlyt (Sy et al., 2018, p. 58.). Ha weberi és a barnardi karizmaértelmezést ezen a szemüvegen keresztül nézzük, akkor

- egyfelől kitünik az, hogy az engedelmességkövetés valójában észlelés kérdése: a beosztott inkább követésként vagy inkább engedelmességként éli-e meg azt?

- a kiindulópont az elfogadás, a küldetés elismerése és az elfogadott zónán, illetve küldetésen belül az utasitásnak megfelelő magatartás inkább tünik követésnek, mint engedelmességnek,

- a hangsúly a kiváltott magatartáson és az annak eredményeként előálló kimeneti teljesítményen (beteljesedett küldetésen) van.

House (1977) mutat rá arra, hogy a kivételes önbizalom, a befolyás megszerzésére és megkövetelésére irányuló erőteljes motiváció és a saját hiedelmek erkölcsi kifogástalanságában való erős meggyőződés azok a vezetői személyiségvonások, amelyek a karizmatikus leadership előzményeinek tekinthetők. McClelland - Burnham (1976) hatalmimotiváció-elmélete bontja ki azt a befolyásra törekvő motivációt, amelynek hangsúlya nem a személy, hanem az általa vezetett intézmény sikerén van - a hatalmi motiváció ezen „társas” értelmezésének lényege a jó teljesítményre ösztönző mikroklíma megteremtése, ami éppenséggel a személyes hatalmi ambíciók visszafogottságával jár. Mudra (2001) a karizmát az intézménnyel szervesen összekapcsolódó fogalomként, előbbit az utóbbi megváltoztatásának képességeként értelmezi.

House et al. (1991) a McClelland-féle elméletet és annak kiterjesztését (LMP = Leader Motive Profile) integrálták saját modelljükbe: ahhoz, hogy a vezető a követők változáshoz elégséges kritikus tömegét mozgósítani tudja a követők és a közösség vízióit megjelenítő vezetői jövőkép megvalósítására, a (társas) hatalmi motiváció magas szintjével kell rendelkeznie. Minthogy azonban ez a követők egy részének ellenállását - és kritikáját - váltja ki, a vezető viszonya ezekhez közömbös, ami az affiliációs motiváció relatíve alacsony mértékével jár együtt. 
Trice - Beyer (1986) a következö öt tényezőben foglalja össze a weberi (szociologikus) karizmaértelmezést: (1) egy rendkívüli tehetségủ személy, (2) egy társadalmi értelemben válságos, de legalább is nehéz helyzet, (3) a válság gyökeres megoldására alkalmas elképzelések halmaza, (4) olyan követők halmaza, akik a kivételes személyiséget vonzónak találják és meg vannak győződve arról, hogy az közvetlenül kötődik transzcendens hatalmakhoz, végül (5) ismétlődő sikerek hitelesítik a kiemelkedő tehetséget és transzcendenciát. Nézetük szerint mind ezek együttállása nélkülözhetetlen ahhoz, hogy a karizma mint szociológiai jelenség felszínre kerüljön (House, 1999, p. 563.).

Weber karizmaértelmezése uralomszociológiájába ágyazottan bontakozik ki. Weber dilemmája is inkább társadalmi, mint szervezeti (Szerb, 1991; Jenei, 2016):

- jóllehet a hatékony közigazgatási szervezeti modellt (bürokráciát) alkotja meg,

- a kihívás azonban, amire választ keres, alapvetően társadalmi léptékủ: a kapitalista gazdasági viszonyrendszer elvárásainak megfelelő elfogulatlan, kiszámítható, a versenyben esélyegyenlőséget lehetővé tevő bürokrácia!

A weberi bürokratikus szervezetet gazdálkodó szervezetekre is adaptálták. Érdemes azonban ennek az adaptációnak három fontos jellemzőjére felhívni a figyelmet:

- míg a bürokratikus szervezet strukturális jellemzői (specializáció, szabályozottság, aktaszerüség - azaz lényegében a magatartáskontroll) Webernél az elfogulatlanságot, kiszámíthatóságot, előrejelezhetőséget, esélyegyenlőséget hivatottak biztosítani, addig ugyanez az eszközrendszer a kor gazdasági szervezetinél (vállalatainál) a képzetlenséget, az összetettebb önálló problémamegoldására való képtelenséget volt hivatott a kezelni,

- Weber közigazgatási szervezetének végrehajtó szintje (a bürokraták) szakmailag képzettek (ez kiválasztásuk, a szervezetbe való belépésük feltétele), vezetőjük ugyanakkor más logika szerint választódik ki: politikai kinevezett politikai alkalmasság alapján. A gazdálkodó szervezet bürokráciájában a végrehajtó szint képzetlen, vezetőjük viszont képzett és tulajdonosi kinevezéssel szakmai alkalmasság alapján választódik ki.

- míg a közigazgatás felől közelítve a karizma és a bürokrácia társadalmi szintü uralmi kérdés és választható viszonyban álló opciók, addig a vállalati bürokráciára való adaptálás során a bürokrácia szervezeti struktúrává, a karizma pedig leadership-pé változik és egymás kiegészítői. Ami a közigazgatás esetében uralomválasztási kérdés, az nem más, mint hogy a közigazgatási szervezetben a müködés feletti kontroll személyes (személyfüggő) vagy racionális (pozíciókhoz és nem személyekhez kötődő, intézményesített) legyen-e. Utóbbi (racionális/bürokratikus uralom) a politikai akarat végrehajtásának a garanciája. Ugyanez a gazdálkodó szervezet esetében teljesen máshogy vetődik fel: a formális szervezeti pozíciók hierarchiája a vezetői problémamegoldást hivatott a feladat-végrehajtás szintjére „letranszformálni”. A karizma ugyanakkor a vezetö-beosztott kapcsolatban leadership: a képzetlen végrehajtó felnéz a nagyobb tudásra, a komplexebb problémamegoldó képességre. Vegyük észre, hogy míg a politikai akarat szerinti kimenő teljesítményt garantáló közigazgatási bürokrácia eredményességi kihívásra adott válasz, a vállalati bürokrácia esetében a kihívás hatékonysági oldalon jelentkezik.

A neokarizmatikus értelmezés a karizmatikusságot ebböl a társadalmi-szociológiai beágyazottságból egyértelmüen szervezeti-vezetési kontextusba helyezi át és szervezeti tényezőként értelmezi és a vezető személyes tulajdonságai (a kiválóság, a „nagy ember” hangsúlyozása) helyett inkább a követést kiváltó magatartást helyezik középpontba.

A neokarizmatikus - immár egyértelmüen szervezeti közegbe ágyazott - leadership értelmezésemben két eltérő logikájú megközelítésen alapszik: az egyik változás-vezetést, a másik a magasrendủ szükségletek kielégítésének vezetői szándékát kapcsolja a fogalomhoz. Előbbi a környezeti, utóbbi a munkavállalói kihívásra adott válasz. Előbbit House, utóbbit Burns fogalmazza meg és mindkettő visszatükrözi azt a 70-80-as évek fordulóján kibontakozó és mindmáig jellemző vezetési-szervezeti paradigmaváltást, amely egyfelől a mindinkább dinamikussá váló környezetben és a nyílt-rendszer koncepcióban, másfelől az érett, magasrendủ motivációi által vezérelt, önálló problémamegoldó munkavállalóban ragadható meg.

Vizsgáljuk meg ezeket részletesebben!

Weber küldetésértelmezését tovább fejlesztve House (1977) mutat rá arra, hogy a karizmatikus vezetők lényegében változásvezetők, a társadalmi változásokhoz nélkülözhetetlen kockázatvállalási hajlandósággal, állhatatossággal, elszántsággal és kitartással. A változásvezetői szerep ugyanakkor jól értelmezhetővé teszi a karizma észlelt természetét is: a változtatási szándék ellenállást vált ki a status quo kedvezményezettjeiből, akik ennek folytán nem fogják karizmatikusnak észlelni őt, inkább negatív színben látják.

Burns (1978) korszakos jelentőségű könyvében két vezetőtípust különböztet meg: az üzletkötő (transactional) és az átalakító (transformational) leadert. A kettőben közös az, hogy a leadership lényegének a cserét tekinti, a megkülönböztetés azon alapul, hogy vezetö és követő mit is cserélnek ki? Burns értelmezésében:

- a leadership a közös-kollektív célhoz kötódik, és hatékonysága az emberi szükségletek és várakozások kielégítésére irányuló szándékban és változásban mérhető meg, ezen belül

- az üzletkötő leadership konkrét, vezető és követő számára hasznos dolgok kölcsönös cseréjét jelenti, míg

- az átalakító leader magasrendủ motivációk kielégítésére törekszik, és figyelmét a követő teljes személyiségére koncentrálja. Az átalakító vezető-kö- 
vető viszony kölcsönösen serkentő és emelkedett, és gyakran változtatja a követőt vezetővé, a vezetőt pedig az erkölcs képviselőjévé (moral agent) (Burns, 1978, p. 4.).

Burns az átalakító vezető fogalmat összekapcsolja a hősiességgel, karizmatikussággal. A morális leadership szerinte értékalapú és egyértelműen olyan társadalmi változásokhoz vezet, amelyért a vezető felelősséget érez és vállal. Burns leader-e erkölcsileg felemelö, és tudatosan törekszik követőit leader-ekké fejleszteni (átalakító) (Avolio, 2000, p. 741.).

Bennis - Nanus (1985), majd Nanus (1992) küldetés és a közös(ségi) cél gondolatát elmélyítve vezetik be a vezetői jövőkép (vízió) fogalmat: „nincs annál erősebb hajtóerő a szervezeti kiválóság és a hosszú távú sikeresség elérésére, mint a jövőnek egy széleskörben osztott vonzó, érdemi és elérhető víziója" (Nanus, 1992, p. 3.).

Az üzletkötő és az átalakító vezetőtípusokat Kotter (1990) operacionalizálja vezetői szerepekké, előbbit a managerként, utóbbit a leaderként címkézve. Kotter a leader szerepet egyben összekapcsolja a változásvezetéssel (change-agent) is.

Conger és Kanungo (1998) szakaszmodelljükben finomítják és kibontják a karizmatikus vezetők változásvezetésre képesítő tulajdonságait és magatartásait, egyben tovább fejlesztve Kotter leader szerepértelmezését is (lásd 1. táblázat).

A GLOBE-kutatás a karizmatikus/értékalapú ledership-et a vezető olyan képességeként határozza, meg, amelynek révén szilárd meggyőződéssel vallott értékei révén inspirálja, motiválja követőit és kiemelkedő kimenő teljesítményt vár el tőlük (House et al., 2004, p. 14.).

\section{A karizmatikus és a neokarizmatikus leadership - a követők nézőpontjából}

Tegyük fel a kérdést: miért következik be a neokarizmatikus átértelmezés a leadership-irodalomban? Nézetem szerint ennek magyarázatát abban ragadhatjuk meg - erre fentebb már utaltam -, hogy a karizmatikus leadership a klasszikus, a neokarizmatikus a versengő paradigma környezeti, illetve munkavállalói kihívásaira adott leadership-válasz!

Argyris (1957a, 1957b, 1973) érettségkoncepciója mutat rá arra, hogy a követők a gyermek-felnőtt (éretlenség-érettség) kontinuumon egyre inkább az érettség felé elmozdulva, egyre magasabb szintű problémamegoldó képességgel és hajlandósággal lépnek be a munka világába:

1) „Az egyének a gyermekkor passzív állapotából a felnőttkor növekvő aktivitása irányába mozdulnak el.

2) Az egyének a gyermekkorra jellemző másoktól való függés állapotából a felnőttkor relatív függetlensége irányába fejlődnek.

3) Az egyének a gyermekkorban jellemzően néhány viselkedési mintát követnek, felnőttként azonban képesek többféle viselkedési mintára.

4) Az egyéneket a gyermekkorban kiszámíthatatlan, véletlenszerü és felületes érdeklődés jellemzi, felnőttkorra ez mélyebbé és összetettebb szövedékűvé válik.

5) A gyermek időhorizontja jellemzően igen rövid és a jelent magába foglaló, érésükkel azonban időhorizontjuk kiterjedt és magába foglalja a múltat és a jövőt is.

6) Az egyének gyermekként mindenkinek alárendeltek, innen azonban felnőttként elmozdulnak a másokkal egyenlő vagy a fölérendelt pozíciók felé.

7) Gyermekként az egyéneknek hiányos az éntudatuk, felnőttként ennek nemcsak hogy tudatában vannak, hanem képesek ,énjüket” kontroll alatt tartani” (Argyris, 1957b, p. 3-4.).

Hackman-Lawler (1971) rámutat ennek a motivációs hátterére: erőteljes az elmozdulás a magasabb rendü (intrinsic) szükségletek kielégítése felé (változatosság, auto-

1. táblázat A karizmatikus vezető tulajdonságai és magatartásmintái Conger - Kanungo szakaszmodellje alapján

\begin{tabular}{|c|c|c|c|}
\hline & $\begin{array}{l}\text { 1. szakasz: a környezeti } \\
\text { kontextus és a jelenlegi } \\
\text { helyzet kritikai értékelése }\end{array}$ & $\begin{array}{l}\text { 2. szakasz: szervezeti célok } \\
\text { megfogalmazása és } \\
\text { artikulációja }\end{array}$ & $\begin{array}{l}\text { 3. szakasz: a megvalósítás } \\
\text { módjának és eszközének } \\
\text { szemléltetése }\end{array}$ \\
\hline \multirow{3}{*}{$\begin{array}{c}\text { Az adott szakaszra jellemző } \\
\text { karizmatikus } \\
\text { vezetői tulajdonságok, } \\
\text { illetve magatartások }\end{array}$} & $\begin{array}{l}\text { A status quo hiányosságai } \\
\text { felismerésének képessége }\end{array}$ & $\begin{array}{l}\text { A jelenlegitől lényegesen } \\
\text { eltérő eszményített jövőkép } \\
\text { megfogalmazása }\end{array}$ & $\begin{array}{c}\text { Eredeti, szokatlan, újszerü, } \\
\text { társadalmi szabályoktól } \\
\text { eltérő }\end{array}$ \\
\hline & $\begin{array}{c}\text { Erős késztetés a status quo } \\
\text { megváltoztatására }\end{array}$ & $\begin{array}{c}\text { Szerethető, azonosulásra és } \\
\text { követésre érdemes közösen } \\
\text { értelmezett távlatok } \\
\text { megfogalmazása }\end{array}$ & $\begin{array}{c}\text { Szavahihető hitelesség, } \\
\text { személyes kockázatokat és } \\
\text { áldozatot is vállaló } \\
\text { szenvedélyes képviselet }\end{array}$ \\
\hline & $\begin{array}{l}\text { A követők hajlamainak, } \\
\text { képességeinek, } \\
\text { szükségleteinek és } \\
\text { elégedettségének } \\
\text { pontos felmérése }\end{array}$ & $\begin{array}{l}\text { A jövőbeli célok erőteljes és } \\
\text { inspiráló artikulációja }\end{array}$ & $\begin{array}{l}\text { Szakértelem a fennálló rend } \\
\text { meghaladására alkalmas } \\
\text { nem szokványos eszközök } \\
\text { alkalmazásában }\end{array}$ \\
\hline
\end{tabular}

Forrás: saját szerkesztés (Conger - Kanungo, 1998, p. 48-57.) alapján 
nómia, munkával való azonosulás, a teljesítményről való visszajelzés). Argyris egy illeszkedési kérdést is tisztáz: a formális szervezetek néhány strukturális jellemzője nincs összhangban az érett személyiség elvárásaival (Argyris, 1957b, p. 20.). Hersey et al. (1996) ugyanakkor szituatív leadership-elméletükben a formális szervezeti jellemzők helyett a feladat/kapcsolatorientált értelmezési keretben vett leadership és az értettség illeszkedését vizsgálják, egyben operacionalizálják is az argyrisi érettséget, melyet egyben modelljük független változójának is tekintenek. Hersey et al. (1996) vezetői nézőpontból kialakított érettség (readiness) fogalma két elemből építkezik: a problémamegoldásra való képesség (skill) és az arra való hajlandóság (will). Modelljük igen erős üzenete, hogy a képességhiány esetén a vezetői feladatorientáltság elkerülhetetlen. Témánk szempontjából ezt úgy fogalmazhatjuk meg, hogy az alacsonyabb érettséggel jellemezhető (hiányos képességű) munkavállalóra probléma nem bízható, neki csak feladatot lehet adni a végrehajtásra vonatkozó egyértelmü instrukciókkal együtt. Ez lényegében magatartáskontroll. Másfelől viszont az érett (kész és képes) személyiségek vezetésében a feladatorientált vezetési elemek eltünnek - a beosztotté a problémamegoldás felelőssége. Ez esetben a vezető-beosztott kapcsolatban a pozícióból fakadó hatalmi eszközök helyét fokozatosan a vezető személyes hatalmi forrásai - a French-Raven-i (1959) értelemben vett szakértői, illetve referens hatalom (azaz a karizma) - veszik át. Ez viszont eredmény- és/vagy klánkontroll alkalmazását vonja maga után.

A munkavállalói érettséghez igazodó leadership-modell érvényességét és erejét alátámasztó tény, hogy a szervezet- és vezetőfejlesztés egyik legelterjedtebben alkalmazott modelljévé vált (Robbins, 1998).

Vessük össze a karizmatikus, illetve neokarizmatikus leadership-et az érettségelmélet nézőpontjából - ez azért is lehet ígéretes megközelítés, mert a környezeti dinamika és komplexitás mellett a beosztotti érettség a vezetésiszervezeti paradigma egyik független változója. Egyben nézőpontot is váltunk: a karizmatikus és a neokarizmatikus leadership közötti különbségtételt a követő perspektívájából gondoljuk végig.

A weberi (klasszikus) karizmatikus vezető követője inkább az argyrisi kontinuum éretlen, míg a neokarizmatikus vezetőé inkább az érett végpontjához van közelebb.

A klasszikus karizmatikus vezető követője még nem önálló problémamegoldó (komplexebb problémák tekintetében legalábbis biztosan nem), a neokarizmatikusé viszont már az.

A klasszikus karizmatikus vezető dominánsan magatartás (bürokratikus) kontrollt, míg a neokarizmatikus teljesítmény- (piaci) vagy klánkontrollt gyakorol. Előbbi egyenes következménye az önálló problémamegoldó képesség hiányának. Utóbbi esetében a követői problémamegoldó képesség már jelen van, így:

- elismertség motivációs szint esetén a kimenő teljesítmény fölötti alku és a ténylegesen teljesítmény alapján történő visszacsatolás,

- önmegvalósítás motiváció esetén a döntések alapvető kognitív (hiedelem természetü), illetve preferenciális (érték) premisszáiban való előzetes megállapodás a kontrollgyakorlás módja.

A klánkontroll alkalmazását Schein (1992, p. 229.) a következőképpen írja le: „A legegyszerübb magyarázat arra, hogy a vezetők hogyan értetik meg üzeneteiket, nem más, mint a karizmájukon keresztül - e rejtélyes tulajdonságon belül az egyik legfontosabb elem a leader azon képessége, hogy elevenen, ugyanakkor tiszta egyértelmüséggel képes a lényeges előfeltevéseket és értékeket kommunikálni. A karizmatikus jövőképnek, mint az ezeket beágyazó mechanizmusnak a legfőbb problémája az, hogy kevés vezető képes erre és hatását ezzel együtt nehéz előre jelezni”.

Mi az, ami a kétféle karizmatikus leadership-et mégis közös nevezőre hozza? Podolny et al. (2000) mutatnak rá a karizmatikus leadership egy lényeges aspektusára: a jelentésadásra. „A karizmatikus leadership mint jelenség, majdhogynem definíciószerüen foglalja magába azt, hogy a követők cselekedeteiket összekapcsolva szeretnék látni életük nagyra értékelt szempontjaival” (ibid, p. 70.). A követő szervezeti valósága egy társas konstrukció folyamatában jön létre, az általa kialakított értelmezés a szervezet tagjai által közösen kialakított jelentésadástól nem függetleníthető: azt egymástól tanulják, nem (feltétlenül) maguk konstruálják - ebben a vezetőnek kitüntetett szerepe van (Gioia, 1986; Isabella, 1990).

Másnak ítélem azonban a karizmatikus, illetve a neokarizmatikus leader által közvetített jelentésadást, a követői értelmezéshez való vezetői hozzájárulást.

A karizmatikus vezető követője - aki még nem önálló problémamegoldó - a saját problémaészlelését meghaladó, annál jóval komplexebb problémaértelmezést várja a vezetőtől és egyben ezt is értékeli benne! A sajátjánál jóval összetettebb, ugyanakkor az önértelmezéséhez és önbecsüléséhez igen fontos hozzájárulást jelentő vezetői értelmezés folyománya ugyanakkor az, hogy a követő:

- a vezetőjét önmaga fölé emeli, és személye iránt elköteleződik,

- a követő odaadóan felnéz vezetöjére, problémaészlelés és -megoldó képességét magáét messze meghaladónak tekinti,

- kész követni, amely mind a karizmatikus vezető céljai, mind a célok megvalósítási módjának az elfogadásában nyilvánul meg,

- a fölérendeltség nem a vezető pozíciójából fakad (ennek folytán nem felülröl kikényszerített), hanem a személyének tulajdonított (azaz Barnard értelmezésével összhangban alulról tételezett),

- vegyük észre, hogy így nyer értelmet a fentebb tárgyalt követés-engedelmesség dilemma: a vezető személyével és ezáltal céljaival való azonosulás követésként értelmezhető, az önmaga fölé való emelésből következő önként vállalt alárendeltség mégis egyfajta hierarchikus viszonyt eredményez, ami - tekintettel arra, hogy a vezető személye iránti odaadás feltétlen - kvázi-hatalmi reláció. 
Más a helyzet a neokarizmatikus vezető követőjével. Ö már - lévén kész és képes önálló problémamegoldó - nem a probléma értelmezését és megoldását, mint jelentésadást várja vezetőjétől, hanem

a) olyan önmagán túlmutató kihívó és vonzó célok megfogalmazását, amelyek a kompetenciák teljes körü mozgósítását igénylik, mi több azok továbbfejlesztésére is lehetőséget kínálnak - vegyük észre, hogy ezek az önmegvalósító motiváció szerves részei,

b) olyan kognitív (hiedelem természetü) és preferenciális (érték jellegü) keretek megteremtését, amelyeknek - mint döntési premisszáknak - a követő általi elfogadása kijelöli az autonóm cselekvés mozgásterét.

Ennek a jelentésadásnak ugyanakkor más a folyománya:

- a vezető-követő viszony sokkal inkább mellérendelt - lévén kettejük függése kölcsönös,

- a követést nem a jobb problémaészlelés és -megoldás képessége, hanem éppenséggel a beosztotti problémamegoldásnak teret engedő vezetésfelfogás és az interperszonális viszonyokat kezelni képes kompetenciák (EQ) megléte váltja ki,

- jóllehet a vezetői befolyás személyhez kötött, a követő mégsem a vezető személye, hanem az általa képviselt célok, illetve értékek és hiedelmek iránt köteleződik el,

- ha a vezető által képviselt célok és kultúra hiteles a követő számára, a leader-követő viszony kölcsönösen elönyös, és a követőben kialakulhat a nyer-nyer játékhoz való feltétlen ragaszkodás, elkötelezödés, amelyért személyes áldozatot is vállal,

- ezt tekinthetjük az indifferencia zóna egy teljesen más szintủ újraértelmezésének is: a számára elfogadhatónak tekintett direktívákat kész követni. A direktívák értelmezéséhez két kiegészítő megjegyzés kívánkozik - mindkettő érdemi különbség a klasszikus karizmatikus leadership-hez képest:

- a neoklasszikus karizmatikus vezető követője számára a direktívák a célról és a célelérést terelő döntési premisszákról szólnak és nem a nem a célelérés módjáról (magatartásról),

- a célok és a döntési premisszák kibernetikai értelemben vezérlés jellegűek: nincs korrekciós jellegü (szabályozó) visszacsatolás. Ha van viszszacsatolás, az kéthurkos jellegü: nem a következményeket kompenzálják, hanem magát a célt, illetve a döntési premisszákat (értékeket, hiedelmeket) változtatják meg!

2. táblázat A karizmatikus és neokarizmatikus leadership összehasonlítása - szempontok és jellemzők

\begin{tabular}{|c|c|c|c|}
\hline & Összehasonlítási szempontok & Karizmatikus & Neokarizmatikus \\
\hline \multirow{2}{*}{$\begin{array}{l}\text { Koncepcionális } \\
\text { fókusz }\end{array}$} & társadalmi szint & $\begin{array}{c}\text { társadalmi-szociológiai } \\
\text { jelenség }\end{array}$ & szervezeti tényező \\
\hline & elméleti hangsúly & $\begin{array}{l}\text { vezetői tulajdonságok, } \\
\text { kiválóság }\end{array}$ & a követést kiváltó magatartás \\
\hline \multirow{4}{*}{$\begin{array}{c}\text { Vezetői } \\
\text { szerepértelmezés }\end{array}$} & hatalom-leadership & $\begin{array}{l}\text { inkább hatalom } \\
\text { (engedelmesség) }\end{array}$ & inkább leadership (követés) \\
\hline & burnsi üzletkötő-átalakító & $\begin{array}{c}\text { érintettek számára fontos } \\
\text { jószágok kölcsönös cseréje } \\
\text { (üzletkötő, zéróösszegű játsz- } \\
\text { ma) }\end{array}$ & $\begin{array}{l}\text { kölcsönös és emelkedett } \\
\text { serkentés (átalakító, moral } \\
\text { agent, nyer/nyer játszma) }\end{array}$ \\
\hline & $\begin{array}{c}\text { kotteri manager-leader } \\
\text { szerepek }\end{array}$ & inkább manager & inkább leader (változásvezető) \\
\hline & vezetőtől elvárt intelligencia & $\begin{array}{c}\text { problémamegoldó intelligencia } \\
\text { (IQ) }\end{array}$ & érzelmi intelligencia (EQ) \\
\hline \multirow{5}{*}{$\begin{array}{l}\text { Vezető-követő } \\
\text { viszony }\end{array}$} & elköteleződés, odaadás & vezető személye iránt & $\begin{array}{c}\text { vezető által képviselt értékek és } \\
\text { célok iránt }\end{array}$ \\
\hline & függés & egyoldalú & kölcsönös \\
\hline & vezetői kontroll & magatartás & teljesítmény vagy klán \\
\hline & kibernetikai visszacsatolás & szabályozás & vezérlés \\
\hline & leaderi jelentésadás & $\begin{array}{c}\text { komplexebb probléma észlelés } \\
\text { és értelmezés }\end{array}$ & $\begin{array}{l}\text { vonzó és önkiteljesítésre } \\
\text { alkalmas cél és az autonóm } \\
\text { cselekvés mozgásterét kijelölő } \\
\text { hiedelem- és értékkeretek }\end{array}$ \\
\hline \multirow{2}{*}{ Követő jellemzői } & követői érettség (Argyris) & $\begin{array}{l}\text { inkább éretlen } \\
\text { (feladat végrehajtó) }\end{array}$ & $\begin{array}{c}\text { inkább érett } \\
\text { (önálló problémamegoldó) }\end{array}$ \\
\hline & $\begin{array}{l}\text { Kielégített követői } \\
\text { szükségletszint (motiváció) }\end{array}$ & extrinsic motivációk (külső) & intrinsic motivációk (belső) \\
\hline
\end{tabular}

Forrás: saját szerkesztés 
A karizmatikus és a neokarizmatikus leadership-értelmezések összehasonlításának legfontosabb szempontjait és jellemzőit a 2. táblázatban foglalom össze.

\section{A neokarizmatikus leadership - tények a Globe-kutatás alapján}

A GLOBE-kutatás vezetési stílust vizsgáló része azokat az elvárt tulajdonságokat, elvárt magatartási mintákat tárja fel, amelyek egy sikeres vezetővel szemben megfogalmazódnak. A kutatás tehát nem az észlelt (leíró), hanem a kívánatos, elvárt (normatív) vezetőképre világít rá. Ez témánk szempontjából azért izgalmas, mert ezek a normatív várakozások éppen a beosztotti nézőpontú elvárásokra mutatnak rá.

A GLOBE-kutatás karizmatikus/értékalapú leadership változójának definícióját olvasva kétségtelen, hogy az a neokarizmatikus értelmezési keretbe illeszthető - nem véletlenül, hiszen a kutatás egyértelműen az ezredfordulóra időszakára jellemző szervezeti-vezetési paradigmába illeszkedik:

„Ez a széles értelemben vett leadership-változó a vezető a szilárd értékmeggyőződésen alapuló inspiráló, motiváló, másoktól magas teljesítményszintet elváró képességét tükrözi”" (House et al., 2004, p. 14.).

A GLOBE leadership megközelítése az implicit leadership-elméletek (ILT) logikáját követi. Eszerint a leadership-pel kapcsolatos elvárás észlelési kérdés, mégpedig a követő nézőpontjából: mindenkinek vannak a vezetőktől elvárt tulajdonságokkal és viselkedésekkel kapcsolatos hiedelmei, meggyőződései, előfeltevései. A vezetőt a követőktől, a sikeres vezetöt a sikertelentől megkülönböztető ezen karakterisztikák alkotják a személyes implicit leadership-elméletünket (Lord-Maher, 1991). Ha ezeket társadalmi szintre aggregáljuk, akkor társadalmi szintű implicit leadership elméletet (CILT - Culturally endorsed implicit leadership theory) kapunk (House et al., 2004, p. 16-17.).

Az implicit leadership-elmélet tehát nem tekinti adottnak a sikeres leadership-pel kapcsolatos elvárásokat, hanem azt a követők által megfogalmazott hiedelmekből, meggyőződésekből és előfeltevésekből építi fel - ez az, aminek a vezetőjük meg kell, hogy feleljen, ha tényleges követést vár tölük.

A GLOBE-kérdőív nagyszámú (112) vezetői tulajdonság, illetve viselkedés 1-7-es skálán való értékelését kérte a kitöltőktől aszerint, hogy mennyire tartják azokat kívánatosnak a vezetői sikeresség szempontjából. Az ezekből kirajzolódó társadalmi szintű elvárásmintázatot (CILTet) faktoranalízissel állították elő. A 62 részt vevő ország több mint 17 ezer középvezetőjének kérdőíves válaszaira alapozott faktoranalízis 21 elsődleges globális leadershipváltozót aggregált. Egy második faktoranalízis ezeket a változókat hat főfaktorba (másodlagos faktorba) tömörítette (Den Hartog et al.,1999). A föfaktorokat és az azokat alkotó elsődleges leadership-változókkal a 3. táblázat mutatja be.
3. táblázat A GLOBE 6 másodlagos leadership-faktora és azok elsődleges összetevői

$\begin{array}{ll}\text { 1. Karizmatikus } & \text { 2. Csoportorientált } \\ \text { - Inspiráló karizmatikus } & \text { • Együttmúködő } \\ \text { - Jövőképpel bíró } & \text { csoportorientáltság } \\ \text { karizmatikus } & \text { • Csoport integrátor } \\ \text { - Önfeláldozó } & \text { • Diplomatikus } \\ \text { karizmatikus } & \text { • Rosszindulat } \\ \text { - Integritáshitelesség } & \text { • Adminisztratív } \\ \text { - Döntésképesség } & \text { kompetencia } \\ \text { - Teljesítményorientáció } & \\ \begin{array}{l}\text { 3. Énközpontú } \\ \text { (Nárcisztikus) }\end{array} & \text { 4. Részvételi } \\ \text { - Énközpontúság } & \text { • Részvételtől elzárkózó } \\ \text { - Státustudatosság } & \text { • Delegáló } \\ \text { - Konfliktusteremtő } & \\ \text { - Önigazoló } & \\ \text { - Procedurális- } & \\ \text { bürokratikus } & \\ \text { 5. Humánorientált } & \\ \text { - Visszafogottság } & \text { 6. Autonóm } \\ \text { • Humánorientáció } & \text { Autonóm }\end{array}$

Forrás: Den Hartog et al. (1999)

A GLOBE izgalmas kutatási kérdése volt az, hogy vajon vannak-e a kiváló vezetőktől univerzálisan elvárt, kultúráktól független leadership-változók? Univerzálisnak a kutatók azokat a változókat tekintik, amelyek az alábbi kritériumoknak felelnek meg (House et al., 2004, p. 677.):

a) az adott változó egyes társadalmak 1-7-es skálán mért átlagainak 95\%-a (egyszerübben: három kivételével) 5 fölötti értéket mutat,

b) a 62 vizsgált társadalom fóátlaga (világátlag) 6 fölötti érték.

A 4. táblázat mutatja be a GLOBE-kutatás karizmatikus leadership adatait:

- a karizmatikus/értékalapú föfaktort,

- annak mind a hat komponensváltozóját,

- kulturális klaszterenkénti (Gupta et al., 2002) csoportosításban, feltüntetve a klaszterátlagokat is.

A táblázat első szembeötlő ténye az, hogy a kompozit karizmatikus/értékalapú főfaktor éppen csak nem felel meg az univerzális követelménynek: jóllehet csak 3 ország (Franciaország, Katar és Marokkó) átlagértéke 5 alatti, a világátlag ,csak” 5,91 (6-nál kevesebb). Lényegében azonban mondhatjuk azt, hogy a neokarizmatikusság egy olyan implicit elvárás a követők részéröl, amely mára - a XX-XXI. század fordulóján - a világ minden vezetőjétől igen erőteljesen elvárt leadership-kompetencia.

Ha a főfaktor hat változó alkotóelemét tekintjük, akkor megállapítható, hogy elsődleges közülük négy karizmatikus komponensváltozó egyértelmüen univerzális: 
- nemcsak igazolható Yukl (2002) tétele, amely a jövőképpel birót és az inspirálót a karizmatikus leadership kritikus tényezőinek tekinti, de ezek egyben univerzálisan elvártak is (rendre: 6,02 és 6,07 világátlagértékek, és minden ország változóértéke 5 fölött van!),

- a hitelesség föátlaga is 6,08, az országok közül csak Katar 5 alatti $(4,83)$,
- a teljesítményorientáció fóátlaga 6,19, ugyancsak Katar 5 alatti értékével $(4,51)$.

Ezek az értékek ugyancsak alátámasztják azt, hogy a neokarizmatikus leadership magától értetődő elvárás a világ valamennyi országában.

Az önfeláldozó karizmatikus és a döntésképes komponensváltozók ugyanakkor nem teljesítik az univerzalitás követelményét.

3. táblázat A GLOBE karizmatikus /értékalapú változójának országonkénti értékei

\begin{tabular}{|c|c|c|c|c|c|c|c|}
\hline Ország & $\begin{array}{c}\text { Jövőképpel } \\
\text { bíró kariz- } \\
\text { matikus }\end{array}$ & $\begin{array}{l}\text { Inspiráló ka- } \\
\text { rizmatikus }\end{array}$ & $\begin{array}{l}\text { Önfeláldozó } \\
\text { karizmatikus }\end{array}$ & Hitelesség & $\begin{array}{l}\text { Döntés- } \\
\text { képesség }\end{array}$ & $\begin{array}{l}\text { Teljesítmény- } \\
\text { orientáció }\end{array}$ & $\begin{array}{l}\text { Karizmati- } \\
\text { kus/érték- } \\
\text { alapú }\end{array}$ \\
\hline Anglia & 6,21 & 6,39 & 4,90 & 6,12 & 6,00 & 6,38 & 6,01 \\
\hline Ausztrália & 6,24 & 6,40 & 5,14 & 6,36 & 6,02 & 6,35 & 6,09 \\
\hline Dél-Afrika (fehér) & 6,15 & 6,33 & 5,01 & 6,35 & 6,07 & 6,01 & 5,99 \\
\hline Írország & 6,33 & 6,33 & 5,11 & 6,19 & 6,14 & 6,38 & 6,08 \\
\hline Kanada (angol) & 6,36 & 6,47 & 5,11 & 6,51 & 6,03 & 6,43 & 6,15 \\
\hline Új-Zéland & 6,23 & 6,50 & 4,88 & 5,49 & 5,69 & 6,31 & 5,87 \\
\hline USA & 6,28 & 6,35 & 5,16 & 6,51 & 5,96 & 6,46 & 6,12 \\
\hline Angol klaszter & 6,26 & 6,40 & 5,04 & 6,22 & 5,99 & 6,33 & 6,04 \\
\hline Ausztria & 6,13 & 6,34 & 5,03 & 6,46 & 5,96 & 6,23 & 6,02 \\
\hline Svájc (németajkú) & 6,12 & 6,25 & 4,88 & 6,36 & 5,86 & 6,08 & 5,93 \\
\hline Hollandia & 6,30 & 6,38 & 4,79 & 6,52 & 5,87 & 5,95 & 5,98 \\
\hline Németország (K) & 5,86 & 6,10 & 5,08 & 6,11 & 5,81 & 6,33 & 5,87 \\
\hline Németország (Ny) & 5,99 & 6,15 & 4,87 & 6,12 & 5,78 & 6,11 & 5,84 \\
\hline Germán & 6,08 & 6,25 & 4,93 & 6,31 & 5,85 & 6,14 & 5,93 \\
\hline Finnország & 6,29 & 6,42 & 4,22 & 6,52 & 5,97 & 6,04 & 5,94 \\
\hline Svédország & 6,05 & 6,31 & 4,81 & 6,29 & 5,59 & 5,96 & 5,84 \\
\hline Dánia & 6,20 & 6,26 & 5,05 & 6,38 & 6,08 & 6,05 & 6,00 \\
\hline Észak-Európa & 6,18 & 6,33 & 4,69 & 6,40 & 5,88 & 6,02 & 5,93 \\
\hline Franciaország & 5,06 & 5,22 & 3,98 & 5,14 & 5,06 & 5,10 & 4,93 \\
\hline Izrael & 6,45 & 6,40 & 5,52 & 6,47 & 6,24 & 6,34 & 6,23 \\
\hline Olaszország & 6,24 & 6,14 & 5,20 & 6,06 & 6,09 & 6,18 & 5,98 \\
\hline Portugália & 6,11 & 6,27 & 4,33 & 6,21 & 5,31 & 6,18 & 5,75 \\
\hline Spanyolország & 5,91 & 6,34 & 4,80 & 6,11 & 5,95 & 6,25 & 5,90 \\
\hline Svájc (franciaajkú) & 6,10 & 6,31 & 5,27 & 6,11 & 5,79 & 5,82 & 5,90 \\
\hline Latin-Európa & 5,98 & 6,11 & 4,85 & 6,02 & 5,74 & 5,98 & 5,78 \\
\hline Albánia & 5,97 & 5,84 & 5,12 & 5,94 & 6,20 & 5,74 & 5,79 \\
\hline Görögország & 6,19 & 6,25 & 5,42 & 6,27 & 6,18 & 5,82 & 6,01 \\
\hline Grúzia & 5,82 & 5,48 & 4,91 & 5,79 & 6,00 & 5,94 & 5,65 \\
\hline Kazahsztán & 5,88 & 5,46 & 4,50 & 5,65 & 5,76 & 5,97 & 5,54 \\
\hline Lengyelország & 6,03 & 5,87 & 4,61 & 5,58 & 6,00 & 5,87 & 5,67 \\
\hline Magyarország & 6,27 & 5,93 & 4,83 & 6,22 & 6,05 & 6,15 & 5,91 \\
\hline Oroszország & 6,07 & 5,93 & 4,28 & 5,72 & 5,95 & 5,92 & 5,66 \\
\hline Szlovénia & 6,00 & 5,74 & 4,77 & 6,08 & 5,79 & 5,76 & 5,69 \\
\hline Kelet-Európa & 6,03 & 5,81 & 4,81 & 5,91 & 5,99 & 5,90 & 5,74 \\
\hline
\end{tabular}


CIKKEK, TANULMÁNYOK

\begin{tabular}{|c|c|c|c|c|c|c|c|}
\hline Argentína & 6,15 & 6,32 & 4,87 & 6,15 & 6,13 & 6,20 & 5,98 \\
\hline Bolívia & 6,20 & 6,28 & 4,94 & 6,29 & 6,27 & 6,04 & 6,01 \\
\hline Brazília & 6,15 & 6,35 & 4,84 & 6,62 & 5,70 & 6,36 & 6,00 \\
\hline Costa Rica & 6,06 & 6,10 & 5,67 & 6,18 & 5,66 & 6,15 & 5,95 \\
\hline Ecuador & 6,50 & 6,63 & 5,99 & 6,79 & 6,29 & 6,64 & 6,46 \\
\hline El Salvador & 6,21 & 6,25 & 5,81 & 6,29 & 5,78 & 6,22 & 6,08 \\
\hline Guatemala & 6,06 & 6,25 & 5,71 & 6,24 & 5,77 & 6,09 & 6,00 \\
\hline Kolumbia & 6,36 & 6,34 & 5,21 & 6,43 & 5,52 & 6,39 & 6,04 \\
\hline Mexico & 5,78 & 5,91 & 4,80 & 5,77 & 5,54 & 6,14 & 5,66 \\
\hline Venezuela & 5,74 & 5,81 & 5,56 & 5,89 & 5,40 & 6,05 & 5,72 \\
\hline Latin-Amerika & 6,12 & 6,22 & 5,34 & 6,26 & 5,81 & 6,23 & 5,99 \\
\hline Dél-Korea & 5,76 & 5,74 & 5,30 & 5,62 & 5,63 & 5,18 & 5,53 \\
\hline Hong Kong & 5,76 & 5,85 & 5,13 & 5,73 & 5,76 & 5,82 & 5,66 \\
\hline Japán & 5,63 & 5,74 & 4,57 & 5,55 & 5,70 & 5,73 & 5,49 \\
\hline Kína & 5,85 & 5,92 & 4,70 & 5,98 & 5,29 & 5,64 & 5,56 \\
\hline Szingapúr & 6,17 & 6,09 & 5,39 & 6,15 & 5,85 & 6,11 & 5,95 \\
\hline Tajvan & 5,66 & 5,74 & 4,98 & 5,89 & 5,60 & 5,67 & 5,58 \\
\hline $\begin{array}{l}\text { Konfuciánus } \\
\text { Ázsia }\end{array}$ & 5,80 & 5,84 & 5,01 & 5,82 & 5,64 & 5,69 & 5,63 \\
\hline India & 6,02 & 5,93 & 5,45 & 5,99 & 5,83 & 5,96 & 5,85 \\
\hline Indonézia & 6,23 & 6,29 & 5,54 & 6,34 & 6,19 & 6,36 & 6,15 \\
\hline Fülöp-szigetek & 6,46 & 6,51 & 5,55 & 6,58 & 6,37 & 6,56 & 6,33 \\
\hline Malájzia & 6,01 & 6,10 & 5,18 & 6,03 & 5,93 & 6,11 & 5,89 \\
\hline Thaiföld & 6,09 & 5,77 & 4,96 & 6,03 & 5,87 & 5,98 & 5,78 \\
\hline Irán & 6,35 & 6,02 & 5,04 & 5,83 & 5,34 & 6,21 & 5,81 \\
\hline Dél-Ázsia & 6,20 & 6,10 & 5,29 & 6,13 & 5,92 & 6,20 & 5,97 \\
\hline Katar & 4,62 & 5,04 & 4,52 & 4,83 & 3,62 & 4,51 & 4,51 \\
\hline Marokkó & 4,84 & 5,09 & 4,10 & 5,03 & 4,70 & 5,10 & 4,81 \\
\hline Törökország & 6,25 & 6,08 & 5,03 & 6,16 & 6,29 & 5,91 & 5,95 \\
\hline Egyiptom & 5,52 & 5,50 & 5,11 & 6,05 & 5,60 & 5,79 & 5,57 \\
\hline Kuwait & 6,22 & 6,16 & 5,16 & 6,19 & 5,58 & 6,08 & 5,90 \\
\hline Arab klaszter & 5,49 & 5,57 & 4,78 & 5,65 & 5,16 & 5,48 & 5,35 \\
\hline Namíbia & 6,16 & 6,26 & 4,79 & 6,35 & 6,16 & 6,16 & 5,99 \\
\hline Zambia & 6,10 & 6,25 & 4,91 & 6,10 & 6,02 & 6,10 & 5,92 \\
\hline Zimbabwe & 6,27 & 6,46 & 5,31 & 6,14 & 6,29 & 6,16 & 6,11 \\
\hline Nigéria & 5,89 & 5,98 & 4,92 & 6,07 & 5,75 & 6,00 & 5,76 \\
\hline $\begin{array}{l}\text { Dél-Afrika } \\
\text { (fekete) }\end{array}$ & 5,39 & 5,56 & 4,33 & 5,36 & 4,83 & 5,47 & 5,16 \\
\hline Fekete-Afrika & 5,96 & 6,10 & 4,85 & 6,00 & 5,81 & 5,98 & 5,79 \\
\hline Cseh Köztársaság & 5,91 & 6,03 & 5,72 & 6,41 & 5,37 & 6,19 & 5,91 \\
\hline Világátlag & 6,02 & 6,07 & 5,00 & 6,08 & 5,79 & 6,19 & 5,91 \\
\hline
\end{tabular}

Forrás: saját szerkesztés House et al. (2004, p. 680.,713-714.) és a GLOBE-kutatócsoport belső munkatáblái alapján 
Tanulságos a kulturális klaszterek közötti összehasonlítás is. A kutatási eredmények arra utalnak, hogy Hummel (1973) érvelése, tudniillik hogy a konfuciánus társadalmakra a karizmatikus leadership nem értelmezhetô, bizonyos árnyalással alátámasztható - talán abban az óvatosabb újra-fogalmazásban, hogy ez az elvárás ebben a kultúrában mérsékeltebb. Amivel a GLOBE-eredmények alapján kiegészíthetjük: a latin-európai, a kelet-európai és a fekete-afrikai klaszterekben is mérsékeltebb az elvárt karizmatikusság, az arab kultúrában pedig még ennél is (szignifikánsan) alacsonyabb (House et al., 2004, p. 682.).

A kelet-európai klaszteren belül izgalmas végig elemezni a magyar adatsort. A föfaktor 5,91-es értéke egyértelműen a klaszterátlag fölött van és a világátlaggal azonos értékü!

Ami a komponensváltozókat (elsődleges faktorokat) illeti:

- a vonzó jövőképet kínáló vezető elvárása mind a klaszter-, mind a világátlagot meghaladó $(6,27)$,

- az inspiráló a világátlag és a klaszterátlag közötti átlagértéket mutat $(5,93)$,

- a vezetőtől várt önfeláldozás belesimul a klaszterátlagba, ám alatta marad a világátlagnak $(4,83)$,

- a hitelesség mind a világ, mind a klaszter átlagait meghaladóan fontos elvárás a magyar kultúrában $(6,22)$,

- hasonlóan mindkét referenciaátlagnál fontosabb a döntésképesség $(6,05)$, és végül

- a teljesítményorientáltság a világátlaghoz közeli, a klaszter megfelelö értékét messze meghaladó elvárás $(6,15)$.

A magyar adatsorról azt érdemes kiemelni, hogy a Kelet-Európa kultúráját jellemző elvárásokhoz képest a magyar vezetök a karizmatikus leadership-et minden elemében fontosabb elvárásként fogalmazzák meg saját vezetőik felé, és ezzel - az egyes változó értékek kismértékű szóródásával együtt - belesimulnak a világátlagba.

\section{Összegzés}

A feldolgozott szakirodalom alapján alátámasztottnak tekintem, hogy a karizmafogalom átértelmeződése a vezetési-szervezeti kontextus paradigmatikus megváltozásának a következménye (1. hipotézis). Az átértelmeződés többrétü:

- a vezetői karizma fogalmát társadalmi kontextusból szervezetibe emelte át,

- uralom-szociológiai fogalomból leadership-fogalommá vált,

- az eredendően klasszikus paradigma kulcsfogalmából (karizmatikus) a versengő paradigma kulcsfogalmává vált (neokarizmatikus) - a kettő más-más vezetési-szervezeti paradigmában értelmezhető,

- kiterjedt nemzetközi leadership-kutatás (GLOBE) is alátámasztja, hogy napjainkra a neokarizmatikus leadership univerzálisan teret nyert (hazai kontextusban is tetten érhető ennek elvárása).
A feldolgozott szakirodalom alapján alátámasztottnak tekintem, hogy napjaink vezetési-szervezeti paradigmájának egyik meghatározó tényezője az önálló problémamegoldásra képes - egyben érett személyiséggel jellemezhető - szervezeti tag (munkavállaló) megjelenése a szervezetben. A vezető az alaptevékenységi feladatorientáltságot teljes egészében elengedve a követöket hatalmazza fel a problémamegoldással, a magatartáskontrollt pedig eredmény- és/vagy klánkontrollal válthatja fel.

Ahogy az argyrisi éretlen-érett skálán egyének és társadalmak elmozdulnak a kész és képes (érett) pólus felé, a szervezeti univerzumban a munkavállalók vezetöikkel szembeni elvárásaiban úgy váltja fel a klasszikus karizmatikust a neokarizmatikus leadership. Ahogy a szervezeti tagok maguk válnak „önjáró” problémamegoldókká, a tevékenységüknek értelmet adó várakozásaik hangsúlya úgy tevődik át a vonzó jövőképre, az önmegvalósítás lehetőségét felkínáló inspiráló és hiteles vezetői viselkedésre, a magas szintü teljesítményre, a képességek mozgósítását, egyben fejlesztését igénylö alkotás lehetőségére. Minél érettebbek vagyunk, illetve minél fejlettebb társadalomban élünk, annál inkább érvényes ez az összefüggés. A neokarizmatikus leadership esetében a követők - mára univerzálisnak tekinthető - összetettebb elvárásai (inspiráció, jelentésadás, értékközvetítés, hitelesség, jövőkép) jelentősen meghatározzák a neokarizmatikus leadership kiemelkedését.

\section{Felhasznált irodalom}

Argyris, C. (1957a): Personality and Organization: the Conflict between System and the Individual. New York: Harper

Argyris, C. (1957b): The Individual and Organization: Some Problems of Mutual Adjustment. Adminsitrative Science Quarterly, Vol. 2, No. 1. (June), p. 1-24.

Argyris, C. (1973): Personality and Organization theory revisited. Adminsitrative Science Quarterly, Vol. 18, No. 2., p. 141-167.

Avolio, B. J. (2000): Pursuing authentic leadership development. In: Nohria, N. - Khurana, R. (eds.): Handbook of Leadership Theory and Practice. Boston: Harvard Business Press, p. 739-768.

Bakacsi Gy. (2011): Egy újra felfedezett óriás: Chester Barnard (1886-1961). In: Dobák M. - Bakacsi Gy. Kiss Csaba (szerk.): Stratégia és menedzsment. Tanulmányok Balaton Károly tiszteletére. Budapest: Aula - Budapesti Corvinus Egyetem Vezetéstudományi Intézet

Bakacsi Gy. (2015): A szervezeti magatartás alapjai. Budapest: Semmelweis Kiadó, 367 p.

Bakacsi Gy. (2015): Változó vezetési paradigma - változó megbízó-ügynök probléma? In: Bakacsi Gy. Balaton K. (szerk.): Vezetés és szervezet társadalmi kontextusban: Tanulmányok Dobák Miklós 60. születésnapja tiszteletére. Budapest: Akadémiai Kiadó, p. 29-54.

Barnard, Ch. I. (1938): The Functions of the Executive. Cambridge: Harvard University Press, 334 p. 
Bass, B. M. (1999): On the taming of charisma: A reply to Janice Beyer. Leadership Quarterly, Vol. 10, No 4, p. 541-553.

Bennis, W. - Nanus, B. (1985): Leaders: The strategies for taking charge. New York: HarperCollins, 235 p.

Burns, J. M. (1978): Leadership. New York: Harper \& Row, 530 p.

Den Hartog, D. N. - House, R. J. - Hanges, P. J. - RuizQuintanilla, S. A. - Dorfman, P. W. - Bakacsi, Gy. et al. (1999): Culture specific and cross culturally generalizable implicit leadership theories: are attributes of charismatic/transformational leadership universally endorsed? Leadership Quarterly, Vol. 10 No.2, p. 219-256.

Diós I. - Viczián J. (szerk.) (2001): Magyar Katolikus Lexikon VI. Kaán-kiz. Budapest: Szent István Társulat, $970 \mathrm{p}$.

Follett, M. P. (1924): Creative experience. Oxford: Longmans, Green \& Co., 303 p.

French, J. R. P-Raven, B. (1959): The basis of social power. In: Cartwright, D. (ed.): Studies in social power. Ann Arbor: University of Michigan Institute for Social Research, p. 150-167.

Gioia, D. A. (1986): Symbols, scripts, and sensemaking. Creating meaning in the organizational experience. In: Sims, H. P. Jr. - Gioia, D. A. (eds.): The thinking organization: dynamics of organizational social cognition. San Francisco: Jossey-Bass, p. 49-74.

Hackman, R. - Lawler, E. E. (1971): Employee reactions to job characteristics. Journal of Applied Psychology, Vol. 55, No. 3, p. 259-286.

Hersey, P. - Blanchard, K. H. - Johnson, D. E. (1996): Management of Organizational Behavior: Utilizing Human Resources (7th ed.). Upper Saddle River: Prentice Hall, $627 \mathrm{p}$.

House, R. J. (1977): A 1976 theory of charismatic leadership. In: Hunt, J. G. - Larson, L. L. (szerk.): Leadership: The cutting edge. Carbonsdale: Southern Illinois University Press, p. 189-207.

House, R. J. - Spangler, D. - Woycke, J. (1991): Personality and charisma in the U.S. Presidency: A psychological theory of leadership effectiveness. Administrative Science Quarterly, Vol. 36, No. 2, p. 364-396.

House, R. J. (1999): Weber and the Neo-charismatic leadership paradigm: A response to Beyer. Leadership Quarterly, Vol 10, No. 4., p. 563-574.

House, R. J.-Hanges, P. J.-Javidan, M. - Dorfman, P. W. - Gupta, V. (eds.) (2004): Culture, leaserhip, and organizations. The GLOBE study of 62 societies. Thousand Oaks: Sage, 818 p.

Gupta, V. - Hanges, P. J. - Dorfman, P. W. (2002): Cultural clusters: methodology and findings. Journal of World Business, Vol. 37, No 1., p. 11-15.

Hummel, R. P. (1973): Charisma in politics: Psychosocial causes of revolution as preconditions of charismatic outbreaks within the framework of Weber's epistemology. Ph.D. thesis (Manuscript). New York: New York University

Isabella, L. A. (1990): Evolving interpretations as a change unfolds: how managers construe key organizational events. Academy of Management Journal, Vol. 33, No. 1, p. 7-41.

Jenei György (2016): Max Weber bürokráciaelmélete és a neoweberiánus szintézis. Pro Publico Bono - Magyar Közigazgatás, No. 3., p. 42-55.

Kotter, J. (1990): What leaders really do? Harvard Business Review, Vol. 68, No. 3, p. 103-111.

Ladkin, D. (2006): The Enchantment of the Charismatic Leader: Charisma Reconsidered as Aesthetic Encounter. Leadership, Vol. 2, No. 2, p.165-179.

Lord, R. G. - Maher, K. J. (1991): People and organizations. Vol. 1. Leadership and information processing: Linking perceptions and performance. Cambridge, MA: Unwin Hyman

McClelland, D. C. - Burnham, D. H. (1976): Power is the great motivator. Harvard Business Review, Vol. 54, No. 2, p. 100-110.

Mudra László (2001): Gondolatok a karizmatikus vezetésről. Vezetéstudomány, Vol. 32, No. 6, p. 56-60.

Nanus, B. (1992): Visionary leadership. San Francisco: Jossey-Bass, $237 \mathrm{p}$.

Nohria, N. - Khurana, R. (eds.) (2000): Handbook of Leadership Theory and Practice. Boston: Harvard Business Press, $822 \mathrm{p}$.

Nye, J. S. (2010): Power and Leadership (p. 305-334). In: Nohria, N. - Khurana, R. (eds.): Handbook of Leadership Theory and Practice. Boston: Harvard Business Press, p. 305-334.

Podolny, J. M. - Khumara, R. - Besharov, M. L. (2000): Revisiting the meaning of leadership. In: Nohria, N. Khurana, R. (eds.): Handbook of Leadership Theory and Practice. Boston: Harvard Business Press, p. 65106.

Robbins, S. P. (1998): Organizational Behavior. Concepts, controversies, applications. Upper Saddle River, NJ.: Prentice-Hall

Schein, E. (1992): Organizational Culture and Leadership. San Francisco: Jossey-Bass Publishers, 418 p.

Szerb László (1991): Max Weber bürokráciaelmélete és a magyar bürokrácia. Aula, Vol. 13, No.3, p. 3852.

Sy, Th. - Horton, C. - Riggio, R. (2018): Charismatic leadership: Eliciting and channeling follower emotions. Leadership Quarterly, Vol. 29, No 1, p. 58-69.

Weber, M. (1996): Gazdaság és társadalom. A megértő szociológia alapvonalai 2/3. Budapest: Közgazdasági és Jogi Könyvkiadó, 281 p.

Yukl, G. A. (2002): Leadership in organization (5th ed.). Upper Saddle River: Prentice Hall, 508 p. 